Arab World English Journal (AWEJ) $2^{\text {nd }}$ Special Issue on Covid 19 Challenges January 2022 DOI: https://dx.doi.org/10.24093/awej/covid2.19

\title{
Recent Trends of Blended Learning and Flipped Classroom in Malaysia
}

\author{
Choy Soon Tan
}

Azman Hashim International Business School, Universiti Teknologi Malaysia, Malaysia

\section{Norhayati Zakuan}

Azman Hashim International Business School, Universiti Teknologi Malaysia, Malaysia Corresponding author: norhayatimz@utm.my

\section{Mohd Ismail Abd Aziz}

Azman Hashim International Business School, Universiti Teknologi Malaysia, Malaysia

Received: 11/8/2021

Accepted: 1/12/2022

Published: $1 / 24 / 2022$

\section{Abstract}

The classroom is where the student and teacher interact, while traditional education uses a Faceto-Face classroom. The unprecedented COVID-19 forced education to shift into an online classroom. Still, numerous researches demonstrate that the pedagogical quality in online classrooms is thus compromised as the educators tend to convert existing face-to-face curriculum that less prioritize intellectual interaction into online ways. Blended learning is not a new yet effective teaching pedagogy, which seems suitable to overcome the challenges as mentioned above as it is a combination of traditional and online modes. Thus, this article summarizes the current trend of blended learning implementation in the Malaysian setting into valuable insight for the practitioner to redesign their pedagogy to meet new norms. This paper assessed and analyzed a total of 22 recent publications that extracted from the Web of Science Database based on three themes that are participant, instrument, and disciplinary. All researches address higher education context, mainly the students' perspectives and neglecting other stakeholders' perspectives. Blended learning is proven practical in multidisciplinary but independent curriculum, and pedagogy redevelopment is mandated. The quantitative methodology is preferable by the researcher in the identification of critical governing factors. Overall, the context of blended learning development in Malaysia remains progressively developing by time. In conclusion, the practice of blended learning implementation is getting diffused in Malaysia due to its flexibility and versatility. However, such effective pedagogy lay on collaborative efforts between various stakeholders, including educators, students, institutional management, policymakers, and parent.

Keywords: blended learning, COVID-19, education, flipped classroom, pedagogical quality

Cite as: Tan, C. S., Zakuan, N., \& Abd Aziz, M. I. (2022). Recent Trends of Blended Learning and Flipped Classroom in Malaysia . Arab World English Journal (AWEJ) $2^{\text {nd }}$ Special Issue on Covid 19 Challenges (2) 290-301. DOI: https://dx.doi.org/10.24093/awej/covid2.19 
Arab World English Journal (AWEJ) 2nd Special Issue on Covid 19 Challenges January 2022

Recent Trends of Blended Learning and Flipped Classroom in Malaysia

Tan, Zakuan \& Abd Aziz

\section{Introduction}

The classroom is where the student and teacher interact, act as the vital component of formal education. A classroom is a place that the teaching and learning process occurs; the educator teaches the knowledge content while the learner response to the delivered content. Wasriep and Lajium (2019) indicated creativity, critical thinking, collaboration, and communication are the four crucial components in the contemporary classroom. The education industry traditionally uses the Face-to-Face classroom, while the unprecedented COVID-19 pandemic forced education to shift online and virtually conducted. Digital transformation and technology advancement is substantially nourishing the pedagogical quality. Contemporary education shall be learner-centered on satisfying varying students' wishes. Pedagogical innovation is one feasible solution to improve pedagogical quality (Naz and Murad, 2017). Pedagogical innovation is largely influenced by educational policy, objectives, and course content. Enhancement of pedagogical innovation could be a transformation of pedagogy, learning styles, teaching strategy, classroom culture, and communication loop. However, numerous recent researches, including Mohd Basar, Norhaini Mansor, Azhar Jamaludin, and Salwana Alias (2021); Ramli, Majid, and Badyalina (2020), demonstrate that the pedagogical quality in online classrooms is thus being compromised amid pandemic. The main reason is that the educators tend to convert existing face-to-face curriculum that less prioritize intellectual interaction into the online ways. Lytras, Sarirete, and Damiani (2020) stated that the current paradigm change is to shift the role of an educator from a content deliverer to a co-partner towards achieving significant knowledge transfer. Numerous new forms of innovative classrooms were introduced to meet such needs. At the same time, blended learning is not a unique yet effective teaching pedagogy that seems suitable to overcome such challenges as it is a combination of traditional and online ways. Blended learning combines face-to-face and online teaching methods as a whole to make classroom interaction effective. Accessibility and flexibility are two out of many critical criteria relevant to online pedagogy (Dhawan, 2020).

Su Ping, Verezub, Adi Badiozaman, and Chen (2020) explained that the flipped classroom is one of many blended learning models that enabled the student to learn the knowledge content online before the actual class. The student spends their real class time on practice-oriented task to reconsolidate the learning. The review of Siti Fatimah, Md Yunus, and Hashim (2019) disclosed that flipped classrooms have been practiced in the Malaysian education system, both the pre-university level and the higher education level. One of the possible reasons for the practicability of flipped classrooms as a contemporary pedagogy is that, as Apaydin and Kaya (2020) explained, both Generation $\mathrm{Z}$ and Alpha prefer quick and concentrated forms of the message. Generation Alpha has more exhibit behavior than Generation Z; their learning track is fast but quickly bored. Similarly, Hashim and Shaari (2020) noted that the flipped classroom pedagogy suits the learning behavior of millennium and Generation $\mathrm{Z}$ because of immediate learning responses and feedback. The unexpected COVID-19 situation causes lots of social change. Social distancing hinders learning effectiveness and reduces the pedagogical quality of online learning. While flipped classroom seems socially suitable and pedagogically practical to the Malaysian education environment, thus, this article aims to summarize the current trend of 
blended learning implementation in the Malaysian setting into a useful value for the practitioner to redesign their pedagogy to meet the new norms.

\section{Literature Review}

The overview of Siti Fatimah et al.(2019) demonstrated the positive practicability of flipped classrooms in Malaysian environment. The flipped classroom is applicable regardless of varying disciplinary and education levels. The researchers evaluated the effectiveness of flipped classrooms from various stakeholders' perspectives. Earlier day, Zainuddin and Attaran (2016) found that the students at the University of Malaya appreciated the flexibility offered by flipped classrooms as students can relearn the given content based on their needs and schedule. The attitude test conducted by Lee (2019) among parents revealed that most flipped classroom parents could observe their children felt happier and motivated in the learning. The majority of flipped classroom parents noticed healthy communication inside the flipped classroom. Hashim and Shaari (2020) found that teachers commonly agreed that flipped classroom has more advantages over the traditional classroom. However, the effectiveness is dependent mainly on the adequacy of administrative support, sufficient resources, and facilities supplied.

Recently, more researchers are evaluating the effectiveness of online flipped classrooms in tackling the compromised pedagogical quality in the time of the pandemic. Azmin et al. (2021) noted that although more than 50\% of students could accept the online flipped classroom approach, inaccurate selection of video lectures may lead to more deteriorate pedagogical quality. Moreover, Daud, Yunus, Juhari, Hassan, and Pauzi (2021) discovered that the medical student felt more comfortable when flipped classroom was additionally complemented with a Kahoot quiz. The overview of Low et al. (2021) written the advantages of the flipped classrooms, including self-regulated learning, active communication, while the existing barriers in the time of pandemic are connectivity issues, device issues, and facility issues. Furthermore, Bin et al. (2021) pointed that additional challenges to online learning include competency of a teacher; self-discipline of a student; readiness and determination of a managements; as well as financial and technical aid of the institution.

\section{Research Method}

This research paper utilizes the secondary data presented in the literature environment, by only examining the journal papers extracted from the Web of Science Database using content analysis. Using three keywords as search formula, only the journal papers that match the criteria were included in the reviewing works. The three selected keywords are flipped classroom, Malaysia, blended learning. As of 15 September 2021, a total of 130 related papers appeared to match the searching criteria. Nonetheless, only 39 cited references published within the year 2019 to 2021 that were highly relevant were selected as critical data. Figure one demonstrates the overall research method. 
Arab World English Journal (AWEJ) 2nd Special Issue on Covid 19 Challenges January 2022

Recent Trends of Blended Learning and Flipped Classroom in Malaysia

Tan, Zakuan \& Abd Aziz

\section{Summary of Data}

Table one gives a result summary with a descending order arrangement by publication year, followed by ascending order of the authors' names.

Table 1. Summary of result

\begin{tabular}{|c|c|c|c|c|}
\hline $\begin{array}{l}\mathrm{N} \\
\mathrm{O}\end{array}$ & Instrument & Participant & $\begin{array}{c}\text { Disciplin } \\
\text { e }\end{array}$ & Subject \\
\hline 1 & $\begin{array}{l}\text { Systematic } \\
\text { review }\end{array}$ & $\begin{array}{l}64 \text { studies } \\
\text { between } \\
2006-2018\end{array}$ & Multiple & $\begin{array}{l}\text { To examine the influences of information systems on technology } \\
\text { acceptance in adopting blended learning, e-learning is the best tool } \\
\text { in managing the blended classroom in higher education. The } \\
\text { author suggests examining the sustainability and applicability of } \\
\text { educational purposes. }\end{array}$ \\
\hline 2 & $\begin{array}{l}\text { Factor } \\
\text { analysis }\end{array}$ & $\begin{array}{l}792 \\
\text { undergraduat } \\
\text { e students }\end{array}$ & Multiple & $\begin{array}{l}\text { To develop and validate measurement scales on students' } \\
\text { experience, Course design, learning experience, and personal } \\
\text { factors are three critical factors in determining students' } \\
\text { satisfaction toward blended learning. }\end{array}$ \\
\hline 3 & $\begin{array}{l}\text { Self-reflection } \\
\text { of accounting } \\
\text { academician }\end{array}$ & $\begin{array}{l}14 \text { Australia, } \\
\text { Indonesia, } \\
\text { Malaysia }\end{array}$ & $\begin{array}{l}\text { Account } \\
\text { ing }\end{array}$ & $\begin{array}{l}\text { To analyze the delivery model in the virtual classroom during a } \\
\text { pandemic, the course delivery is effective with a combination of } \\
\text { existing resources, learning management system, and support. At } \\
\text { the same time, online assessment is the hiccup as student cheating } \\
\text { is hardly avoided in the virtual classrooms. }\end{array}$ \\
\hline 4 & $\begin{array}{l}\text { Quasi } \\
\text { experimental } \\
\text { analysis }\end{array}$ & $\begin{array}{l}-60 \\
\text { polytechnic } \\
\text { students of } \\
\text { ESL learner }\end{array}$ & $\begin{array}{l}\text { Linguisti } \\
\mathrm{C}\end{array}$ & $\begin{array}{l}\text { To measure the effectiveness of blended learning in improving } \\
\text { English writing skills, blended learning has proven more effective as } \\
\text { a compared traditional method but largely governed by students' } \\
\text { initiation and learners' self-discipline. }\end{array}$ \\
\hline 5 & $\begin{array}{l}\text { Mixed of } \\
\text { survey and } \\
\text { interview }\end{array}$ & $\begin{array}{l}178 \\
\text { Malaysian } \\
\text { medical } \\
\text { students }\end{array}$ & Medical & $\begin{array}{l}\text { To evaluate readiness, self-regulation, and challenges of medical } \\
\text { students in adapting to online learning. The barriers are an } \\
\text { unconducive learning environment, unstable connectivity. }\end{array}$ \\
\hline 6 & $\begin{array}{l}\text { Mixed of } \\
\text { survey and } \\
\text { discussion } \\
\text { board }\end{array}$ & $\begin{array}{l}\text { Postgraduate } \\
\text { ESL student }\end{array}$ & $\begin{array}{l}\text { Linguisti } \\
\text { c }\end{array}$ & $\begin{array}{l}\text { To establish the relationship between Community of Inquiry and } \\
\text { Global Englishers' participation. The author highlights the } \\
\text { importance of Global Englishers' consciousness in empowering the } \\
\text { future research possibilities and output. }\end{array}$ \\
\hline 7 & $\begin{array}{l}\text { Quantitative } \\
\text { online survey }\end{array}$ & $\begin{array}{l}1811 \\
\text { Malaysian } \\
\text { universitys' } \\
\text { students }\end{array}$ & Multiple & $\begin{array}{l}\text { To develop a predictor model in determining student acceptance } \\
\text { and deployment on blended learning by planned behavior theory in } \\
\text { Malaysian perspective, major causal factors are attitude, norm, } \\
\text { perception, behavior, and self-efficacy. }\end{array}$ \\
\hline 8 & $\begin{array}{l}\text { Quantitative } \\
\text { survey } \\
\text { questionnaire }\end{array}$ & $\begin{array}{l}563 \\
\text { Malaysian } \\
\text { universitys' } \\
\text { students }\end{array}$ & $\begin{array}{l}\text { Multim } \\
\text { edia }\end{array}$ & $\begin{array}{l}\text { To measure the causal relationship between self-regulated learning } \\
\text { on the enhancement of digital literacy, three major causal factors } \\
\text { on digital literacy are metacognitive knowledge, resource } \\
\text { management, and motivational belief. }\end{array}$ \\
\hline 9 & $\begin{array}{l}\text { Quantitative } \\
\text { survey }\end{array}$ & $\begin{array}{l}\text { - } 223 \text { IT } \\
\text { administrator }\end{array}$ & IT & $\begin{array}{l}\text { To evaluate the causal relationship between institutions' } \\
\text { administration readiness on diffusion initiative of blended learning, } \\
\text { five factors are institutional structure, resource support, technology } \\
\text { infrastructure, management strategies, and ethical consideration. }\end{array}$ \\
\hline
\end{tabular}

Arab World English Journal

www.awej.org

ISSN: 2229-9327 
Arab World English Journal (AWEJ) 2nd Special Issue on Covid 19 Challenges January 2022

Recent Trends of Blended Learning and Flipped Classroom in Malaysia

Tan, Zakuan \& Abd Aziz

\begin{tabular}{|c|c|c|c|c|}
\hline $\begin{array}{l}1 \\
0\end{array}$ & $\begin{array}{l}\text { Quantitative } \\
\text { survey }\end{array}$ & $\begin{array}{l}256 \\
\text { Malaysian } \\
\text { pharmacy } \\
\text { students }\end{array}$ & $\begin{array}{l}\text { Pharma } \\
\text { cy }\end{array}$ & $\begin{array}{l}\text { To evaluate the acceptance and perception of pharmacy students in } \\
\text { flipped classrooms, results disclose low acceptance and unfavorable } \\
\text { impressions of flipped classrooms among students due to } \\
\text { inappropriate use and additional workload on the student. }\end{array}$ \\
\hline $\begin{array}{l}1 \\
1\end{array}$ & Online survey & $\begin{array}{l}409 \\
\text { respondents }\end{array}$ & Multiple & $\begin{array}{l}\text { To examine mediating causal relationship of peer influence on } \\
\text { online learning, learning satisfaction is fully mediated by self- } \\
\text { discipline, while students' ability to learn with peers significantly } \\
\text { influences their happiness. }\end{array}$ \\
\hline $\begin{array}{l}1 \\
2\end{array}$ & $\begin{array}{l}\text { Open ended } \\
\text { survey }\end{array}$ & $\begin{array}{l}\text { - } 284 \text { online } \\
\text { survey }\end{array}$ & ultiple & $\begin{array}{l}\text { To evaluate the readiness of Malaysian university students in } \\
\text { adapting online learning, results revealed three lacking are } \\
\text { physically, environmentally, and psychological perspectives; the } \\
\text { existing challenge is to shift existing curriculum and assessment into } \\
\text { fully online. }\end{array}$ \\
\hline $\begin{array}{l}1 \\
3\end{array}$ & Overview & $\begin{array}{l}\text { Literature } \\
\text { review }\end{array}$ & ultiple & $\begin{array}{l}\text { To develop a blended learning module for postgraduate research } \\
\text { methodology course, eight proposed modules can integrate } \\
\text { traditional classrooms with web-based approaches. }\end{array}$ \\
\hline $\begin{array}{l}1 \\
4\end{array}$ & $\begin{array}{l}\text { Semi } \\
\text { structured } \\
\text { interview }\end{array}$ & $\begin{array}{l}18 \text { int } \\
\text { respor }\end{array}$ & guisti & $\begin{array}{l}\text { To trace the effectiveness of the flipped classroom in writing class, } \\
\text { the result revealed greater time allocation spent before class, } \\
\text { extensive practical, enhanced engagement, rich communication, } \\
\text { and instant feedback in class and the shortcoming is boredom and } \\
\text { lengthy. }\end{array}$ \\
\hline $\begin{array}{l}1 \\
5\end{array}$ & $\begin{array}{l}\text { Quasi } \\
\text { experimental }\end{array}$ & $30 \mathrm{MCQ}$ & ary & $\begin{array}{l}\text { To evaluate the effectiveness of problem-solving-based classroom } \\
\text { in culinary art program but no significant observed between } \\
\text { intervention, proven similar effectiveness. }\end{array}$ \\
\hline $\begin{array}{l}1 \\
6\end{array}$ & $\begin{array}{l}\text { Quantitative } \\
\text { analysis }\end{array}$ & $\begin{array}{l}41 \text { students' } \\
\text { test result }\end{array}$ & ience & $\begin{array}{l}\text { To evaluate the effectiveness of the formative e-assessment } \\
\text { procedure integrated into a blended learning setting, students' } \\
\text { performance enhanced as learning consolidation easier. }\end{array}$ \\
\hline $\begin{array}{l}1 \\
7\end{array}$ & $\begin{array}{l}\text { Quantitative } \\
\text { survey }\end{array}$ & $\begin{array}{l}87 \text { students } \\
\text { and staffs }\end{array}$ & iple & $\begin{array}{l}\text { To evaluate effectiveness from learners' and staffs' perspectives, } \\
\text { the causal factors are attitude, behavior, satisfaction, resource } \\
\text { management, and ease of use. }\end{array}$ \\
\hline $\begin{array}{l}1 \\
8\end{array}$ & $\begin{array}{l}\text { Quasi } \\
\text { experimental }\end{array}$ & $\begin{array}{l}137 \text { grade } \\
\text { point }\end{array}$ & $\begin{array}{l}\text { Pharma } \\
\text { cy }\end{array}$ & $\begin{array}{l}\text { To measure the effectiveness of flipped classrooms in improving } \\
\text { the academic performance of low pass rate courses, students able } \\
\text { to achieve more excellent academic performance. }\end{array}$ \\
\hline $\begin{array}{l}1 \\
9\end{array}$ & $\begin{array}{l}\text { Qualitative } \\
\text { interview }\end{array}$ & 15 lecturers & tiple & $\begin{array}{l}\text { To evaluate the lecturers' perspective on } \mathrm{MOOC} \text {, identified themes } \\
\text { are educational change, instructional design, motivation, and } \\
\text { challenges. }\end{array}$ \\
\hline $\begin{array}{l}2 \\
0\end{array}$ & $\begin{array}{l}\text { Cross } \\
\text { sectional } \\
\text { study }\end{array}$ & $\begin{array}{l}45 \text { students' } \\
\text { grade }\end{array}$ & $\begin{array}{l}\text { Dentistr } \\
\mathrm{y}\end{array}$ & $\begin{array}{l}\text { To compare the effectiveness of blended classroom to traditional } \\
\text { didactic lecture on dentistry subject, higher score mark for blended } \\
\text { classroom student compared to a conventional classroom. }\end{array}$ \\
\hline $\begin{array}{l}2 \\
1\end{array}$ & $\begin{array}{l}\text { Systematic } \\
\text { review }\end{array}$ & $\begin{array}{l}19 \text { research } \\
\text { articles }\end{array}$ & ultiple & $\begin{array}{l}\text { To review educational level, instruments, and disciplinary of flipped } \\
\text { approach in Malaysia, most studies have positive output, and it is } \\
\text { versatile to apply to all education levels and disciplinaries. }\end{array}$ \\
\hline $\begin{array}{l}2 \\
2\end{array}$ & $\begin{array}{l}\text { Qualitative } \\
\text { survey }\end{array}$ & $\begin{array}{l}141 \text { faculty } \\
\text { staff and } 445 \\
\text { students }\end{array}$ & $\begin{array}{l}\text { Linguisti } \\
\mathrm{c}\end{array}$ & $\begin{array}{l}\text { To compare the quality blended course between the United States } \\
\text { and Malaysia context, the similarity is institution has varying quality } \\
\text { priority while the difference is unique trajectory. }\end{array}$ \\
\hline
\end{tabular}

Arab World English Journal

ISSN: 2229-9327

www.awej.org 
1.(Al-Maroof et al., 2021); 2.(Bhagat et al., 2021); 3.(Djajadikerta et al., 2021); 4.(Hassan et al., 2021), 5.(Roslan and Halim, 2021); 6.(Smidt et al., 2021); 7.(Anthony Jnr et al., 2020); 8.(Anthonysamy et al., 2020); 9.(Bokolo et al., 2020); 10.(Chan et al., 2020); 11.(Lim et al., 2020); 12.(Nassr et al., 2020); 13.(Rahim et al., 2020); 14.(Su Ping et al., 2020); 15.(Techanamurthy et al., 2020); 16.(Wong et al., 2020); 17.(Anthony et al., 2019); 18.(Goh and Ong, 2019); 19.(Nagaletchimee, 2019); 20.(Paul et al., 2019); 21.(Siti Fatimah et al., 2019); 22.(Smidt et al., 2019).
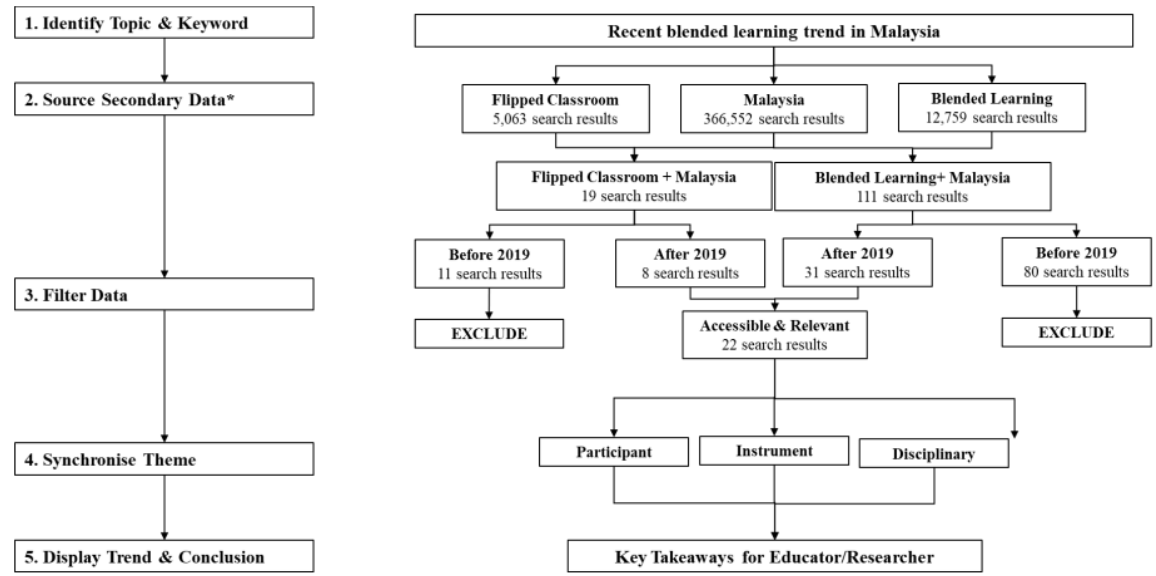

Figure 1. Research method

\section{The Practicability in Malaysia Context}

The discussion pertaining to the practicability of blended learning and flipped classrooms will be explained based on three perspectives, including participant, instrument, and disciplinary.

\section{Participants}

Table two demonstrated the level of participants of the analyzed articles. Most of the research participant dataset is students in Malaysia, including thirteen, are undergraduate student grouping, one postgraduate student grouping, and two research articles focusing on a mixture of students and academicians grouping. The student is not the sole stakeholder in education; both academicians and administrative personnel are deeply integrated into the educational ecosystem. Therefore there are three research articles, including Djajadikerta et al. (2021), Bokolo et al. (2020), Nagaletchimee (2019), that evaluated how institutional, mainly the staff contribute to the effectiveness of blended learning. The study of Nagaletchimee (2019) used a qualitative case study to identify the challenges faced by fifteen lecturers who were familiar with blended learning when they wanted to make a change from the traditional classroom. The results revealed that practical workshops play a vital role in the transformation effort. Although the academician is not rejecting the transition, some obvious challenges are that the academician would not be able to pass through by themselves sorely. 
Similarly, the quantitative work of Bokolo et al. (2020) on e-learning administrative staff disclosed that institutional readiness significantly influences the adoption rate of blended learning. The author developed a model for evaluating institutional readiness on blended learning. More recently, Djajadikerta et al. (2021) noted that without compliance technologies support from the university, such as establishing of a learning management system.

Even though none of the participants in the 22 cited references measured the response of preuniversity students, the systematic review of Siti Fatimah et al. (2019) revealed the practicability of the flipped classrooms at different educational levels in the Malaysian education system. In the past, several flipping learning has been implemented in both the preschool and elementary school levels in Malaysia. In addition, a previous researcher, Chun and Sathappan (2020), conducted the flipped classroom on Year 4 elementary school students and proven effective.

Table 2. Participant type of the analyzed articles

\begin{tabular}{|l|l|l|}
\hline Participant & Frequency & Author \\
\hline Undergraduates & 13 & $\begin{array}{l}\text { Bhagat et al. (2021), Hassan et al. (2021), Roslan and Halim (2021), Anthony } \\
\text { Jnr et al. (2020), Anthonysamy et al. (2020), Chan et al. (2020), Lim et al. } \\
\text { (2020), Nassr et al. (2020), Su Ping et al. (2020), Techanamurthy et al. (2020), } \\
\text { Wong et al. (2020), Goh and Ong (2019), Paul et al. (2019) }\end{array}$ \\
\hline Articles & 3 & Al-Maroof et al. (2021), Rahim et al. (2020), Siti Fatimah et al. (2019) \\
\hline Staff & 3 & Djajadikerta et al. (2021), Bokolo et al. (2020) Nagaletchimee (2019) \\
\hline Mixture & 2 & Anthony et al. (2019), Smidt et al. (2019) \\
\hline Postgraduate & 1 & Smidt et al. (2021) \\
\hline
\end{tabular}

\section{Disciplinary}

Generally, blended learning is practical to all disciplines, as illustrated in Table three. However, linguistic is still a good discipline that led the transformation. Four articles that focus solely on linguistic, mainly English as a second language. The review work of Siti Fatimah et a. (2019) disclosed the similar observation that nine out of nineteen articles reviewed focused on English as a second language. Hassan et al. (2021) have proven that blended learning significantly improves students' writing skills, while Smidt et al. (2021) believed that blended learning empowers global Englishers in developing possible research opportunities. Earlier, Su Ping et al. (2020) used qualitative data to illustrate that linguistic students have positive experiences with blended learning. Contradictory, the authors noted that the weaknesses of their conducted mode are very time-consuming as more thorough preparation was compulsory for efficient learning.

Interestingly, Smidt et al. (2019) evaluated the meaning of quality between American and Malaysian contexts and found that the experience is somewhat dissimilar. Malaysia as a developing mode is prioritized on a technological end while American, as a skilled mode, focused more on standardization. Therefore, it could be summarized that blended learning is very versatile to any disciplinary knowledge as shown in Table three that blended learning was also applied to other disciplines, including information technology, pharmacy, accounting, medical, culinary, dentistry, science. Despite blended learning being proven practical in 
multidisciplinary, the effectiveness is governed by independent curriculum and pedagogy redevelopment to suit the learning behavior and subject matter. The systematic review of AlMaroof et al. (2021) noted that the major of the studies are focused on measuring how effective blended learning is in various disciplinary. The authors intend to highlight here is that the comparison of effectiveness among different educational punitive is an exciting topic that untapped and worth further exploring.

Table 3. Disciplines done of the analyzed articles

\begin{tabular}{|l|l|l|}
\hline Disciplinary & Frequency & Author \\
\hline Multiple & 9 & $\begin{array}{l}\text { Al-Maroof et al. (2021), Bhagat et al. (2021), Anthony Jnr et al. (2020), Lim et al. } \\
\text { (2020), Nassr et al. (2020), Rahim et al. (2020), Anthony et al. (2019), } \\
\text { Nagaletchimee (2019), Siti Fatimah et al. (2019) }\end{array}$ \\
\hline Linguistic & 4 & Hassan et al. (2021), Smidt et al. (2021), Su Ping et al. (2020), Smidt et al. (2019) \\
\hline Technology & 2 & Anthonysamy et al. (2020), Bokolo et al. (2020) \\
\hline Pharmacy & 2 & Chan et al. (2020), Goh and Ong (2019) \\
\hline Accounting & 1 & Djajadikerta et al. (2021) \\
\hline Culinary & 1 & Techanamurthy et al. (2020) \\
\hline Dentistry & 1 & Paul et al. (2019) \\
\hline Medical & 1 & Roslan and Halim (2021) \\
\hline Science & 1 & Wong et al. (2020) \\
\hline
\end{tabular}

\section{Research Instruments}

Despite the fact that every researcher has own pursuit of blended learning, the quantitative method is a better research methodology as compared to the qualitative approach, systematic review, reflection, etc., as shown in Table four. Among eight research that adopts the quantitative method, four of them utilized the partial least square method in determining significant relationships in the blended learning framework. Anthony et al. (2019) evaluated the critical factors on how the institutional influencing blended learning adoption, while Anthony Jnr et al. (2020) evaluated the essential elements on students adoption in university. Similarly, Anthonysamy et al. (2020) investigated how students' self-discipline enhanced digital literacy in blended learning experiences. Lastly, Bhagat et al. (2021) constructed a model for evaluating students' learning experiences. There is a trend that besides students' expertise, institutional policy and students' initiatives also play equal importance. Worth noting that quasiexperimental research design is also a sound research methodology in comparing the effectiveness of blended learning to traditional mode, including the students' writing skills (Hassan et al., 2021), students' grades (Goh and Ong, 2019), and students' problem-solving skills (Techanamurthy et al., 2020). Gopalan et al. (2020) stated that a quasi-experimental research design could effectively reflect how the intervention causes significant change to the observed outcome without yielding a little treated effect. 
Arab World English Journal (AWEJ) 2nd Special Issue on Covid 19 Challenges January 2022

Recent Trends of Blended Learning and Flipped Classroom in Malaysia

Tan, Zakuan \& Abd Aziz

Table 4. The methodology used in the analyzed articles

\begin{tabular}{|l|l|l|}
\hline Methodology & Frequency & Author \\
\hline Quantitative & 8 & $\begin{array}{l}\text { Bhagat et al. (2021), Anthony Jnr et al. (2020), Anthonysamy et al. (2020), Bokolo } \\
\text { et al. (2020), Chan et al. (2020), Lim et al. (2020), Nassr et al. (2020), Anthony et } \\
\text { al. (2019), Paul et al. (2019) }\end{array}$ \\
\hline Interview & 3 & Su Ping et al. (2020), Wong et al. (2020) Nagaletchimee (2019) \\
\hline $\begin{array}{l}\text { Quasi- } \\
\text { experiment }\end{array}$ & 3 & Hassan et al. (2021), Techanamurthy et al. (2020), Goh and Ong (2019) \\
\hline Review & 3 & Al-Maroof et al. (2021), Rahim et al. (2020), Siti Fatimah et al. (2019) \\
\hline Mixed & 2 & Roslan and Halim (2021), Smidt et al. (2021) \\
\hline $\begin{array}{l}\text { Qualitative } \\
\text { Survey }\end{array}$ & 1 & Smidt et al. (2019) \\
\hline Reflection & 1 & Djajadikerta et al. (2021) \\
\hline
\end{tabular}

\section{Discussion and Conclusion}

The blended learning and flipped classroom were not new pedagogy in Malaysia but getting more attention and enhancement, especially amid pandemics. Research output demonstrated that blended learning is proven practical in multidisciplinary but independent curriculum and pedagogy redevelopment is mandated to make it efficient. The quantitative methodology is still preferable in the Malaysian research context because blended learning development is still immature compared to developed nations. Most of researchers tend to identify the critical governing factors on pedagogy change from traditional learning into blended learning. However, almost all of them are lean toward the higher education context, mainly the students' perspective.

Nonetheless, other stakeholders' perspectives, such as policymakers and institutional staff, shall be considered in blended learning adoption. Other relevant parties' input, such as academicians, community, and industry players, could also give a more comprehensive understanding in expediting the adoption. This review article aims to provide helpful insight for practitioner to redesign their pedagogy to meet new norms. Hence, in conclusion, the practice of blended learning implementation is getting diffused in Malaysia due to its flexibility and versatility. However, such effective pedagogy lay onto collaborative efforts between various stakeholders, including educators, students, institutional management, policymakers, and parent.

\section{About the Authors: \\ Dr Choy Soon Tan received the degree in civil engineering and the Ph.D. Degree in civil engineering from the Universiti Teknologi Malaysia. He joined UCSI University as an Assistant Professor after he obtained the Ph.D. degree. Later, he has also been worked as a Senior Project Manager in a Fortune 500 property developer. Currently, he is an MBA student of Azman Hashim International Business School. ORCID: https://orcid.org/0000-0002-2776-1593}

Associate Professor Dr Norhayati Zakuan received the degree in mechanical engineering from the Universiti Teknologi Malaysia, the M.Sc. Degree in engineering and manufacturing management from Coventry University, and the Ph.D. Degree in mechanical engineering (quality) from the Universiti Teknologi Malaysia. She has more than 15 year's industrial 
Arab World English Journal (AWEJ) 2nd Special Issue on Covid 19 Challenges January 2022

Recent Trends of Blended Learning and Flipped Classroom in Malaysia

Tan, Zakuan \& Abd Aziz

experience before joining UTM and currently an Associate professor with the Azman Hashim International Business School. ORCID: https://orcid.org/0000-0002-4872-6404

Professor Dr. Mohd Ismail Abd Aziz is currently an Adjunct Professor of Azman Hashim International Business School, UTM. He received the degree in applied mathematics from the University of New South Wales, the M.Sc. Degree in mathematics from the Loughborough University, and the Ph.D. Degree in control engineering from the City University London. He published over 40 publications in international and national journal. ORCID: https://orcid.org/0000-0003-3537-7353

\section{References}

Al-Maroof, R., Al-Qaysi, N., Salloum, S. A., \& Al-Emran, M. (2021). Blended Learning Acceptance: A Systematic Review of Information Systems Models. Technology, Knowledge and Learning, 1-36.

Anthony, B., Kamaludin, A., Romli, A., Raffei, A. F. M., Nincarean, A., L Eh Phon, D., ... \& Baba, S. (2019). Exploring the role of blended learning for teaching and learning effectiveness in institutions of higher learning: An empirical investigation. Education and Information Technologies, 24(6), 3433-3466.

Anthony Jnr, B., Kamaludin, A., Romli, A., Raffei, A. F. M., Phon, D. N. A. E., Abdullah, A., ... \& Baba, S. (2020). Predictors of blended learning deployment in institutions of higher learning: theory of planned behavior perspective. The International Journal of Information and Learning Technology, 37(4), 179-196.

Anthonysamy, L., Koo, A. C., \& Hew, S. H. (2020). Self-regulated learning strategies in higher education: Fostering digital literacy for sustainable lifelong learning. Education and Information Technologies, 25, 2393-2414.

Apaydin, Ç., \& Kaya, F. (2020). An analysis of the preschool teachers' views on Alpha generation" European Journal of Education Studies, 6(11), 123-141.

Azmin, N. F. M., Abd Wahab, M. F., Ahmad, F., Asnawi, A. L., Jusoh, A. Z., Ibrahim, S. N., \& Jimat, D. N. (2021). Engineering Students' Perceptions and Acceptance of the Online Flipped Classroom for Learning during the COVID-19 Pandemic. IIUM Journal of Educational Studies, 9(3), 52-62.

Bhagat, K. K., Cheng, C. H., Koneru, I., Fook, F. S., \& Chang, C. Y. (2021). Students' Blended Learning Course Experience Scale (BLCES): development and validation. Interactive Learning Environments, 1-11.

Bin, A., Latif, A., Wahida, F., Mohd, B., Nazarudin, A., Bachok, F., and Othman, Z. (2021). Issues and challenges of online learning during COVID-19. GADING, 24(04), 43-48.

Bokolo, A., Kamaludin, A., Romli, A., Mat Raffei, A. F., A/L Eh Phon, D. N., Abdullah, A., Leong Ming, G., A. Shukor, N., Shukri Nordin, M., and Baba, S. (2020). A managerial perspective on institutions' administration readiness to diffuse blended learning in higher education: Concept and evidence. Journal of Research on Technology in Education, 52(1), 37-64.

Chan, S. Y., Lam, Y. K., and Ng, T. F. (2020). Students' perception on initial experience of 
flipped classroom in pharmacy education: Are we ready? Innovations in Education and Teaching International, 57(1), 62-73.

Chun, T. W., and Sathappan, R. (2020). Using flipped classroom approach to teach adjectives for Malaysian Year 4 Chinese ESL learners 41. The English Teacher, 49(1), 41-54.

Daud, N., Yunus, N. I., Juhari, S. N., Hassan, N. M., \& Pauzi, M. F. (2021). Teaching Medical Ethics During Covid-19 Pandemic: An Experience Using Flipped Classroom and GameBased Learning Running head: Online Flipped classroom and Kahoot. Asian Journal of Medicine and Biomedicine, 5(2), 6-15.

Dhawan, S. (2020). Online learning: A panacea in the time of COVID-19 crisis. Journal of Educational Technology Systems, 49(1), 5-22.

Djajadikerta, H. G., Trireksani, T., Ong, T., Roni, S. M., Kazemian, S., Zhang, J., Noor, A. H. M., Ismail, S., Ahmad, M. A. N., Azhar, Z., Shahbudin, A. S. M., Maradona, A. F., Yanto, H., and Wahyuningrum, I. F. S. (2021). Australian, malaysian and indonesian accounting academics' teaching experiences during the COVID-19 pandemic. Australasian Accounting, Business and Finance Journal, 15(2), 103-113.

Goh, C. F., and Ong, E. T. (2019). Flipped classroom as an effective approach in enhancing student learning of a pharmacy course with a historically low student pass rate. Currents in Pharmacy Teaching and Learning, 11(6), 621-629.

Gopalan, M., Rosinger, K., and Ahn, J. Bin. (2020). Use of Quasi-Experimental research designs in education research: Growth, promise, and challenges. Review of Research in Education, 44(1), 218-243.

Hashim, N. A., and Shaari, N. D. (2020). Malaysian teachers' perception and challenges toward the implementation of flipped learning approach. Asian People Journal, 3(2), 62-76.

Hassan, I., Abdul Rahman, A. M., and Latiff Azmi, M. N. (2021). Development of english writing skills through blended learning among ESL learners in Malaysia. Arab World English Journal (AWEJ), 7, 377-389.

Lee, S. Y. (2019). Promoting active learning and independent learning among primary school students using flipped classroom. International Journal of Education, Psychology and Counseling, 4(30), 324-341.

Lim, C. L., Jalil, H. A., Ma'rof, A. M., and Saad, W. Z. (2020). Self-regulated learning as a mediator in the relationship between peer learning and online learning satisfaction: A study of a private university in Malaysia. Malaysian Journal of Learning and Instruction, $17(1), 51-75$.

Low, M. C., Lee, C. K., Sidhu, M. S., Lim, S. P., Hasan, Z., and Lim, S. C. (2021). Blended learning to enhanced engineering education using flipped classroom approach: An overview. Electronic Journal of Computer Science and Information Technology, 7(1), 919.

Lytras, M., Sarirete, A., and Damiani, E. (2020). Technology-enhanced learning research in higher education: A transformative education primer. Computers in Human Behavior, 109(March), 1-3.

Mohd Basar, Z., Norhaini Mansor, A., Azhar Jamaludin, K., and Salwana Alias, B. (2021). The Effectiveness and Challenges of Online Learning for Secondary School Students-A Case 
Arab World English Journal (AWEJ) 2nd Special Issue on Covid 19 Challenges January 2022

Recent Trends of Blended Learning and Flipped Classroom in Malaysia

Tan, Zakuan \& Abd Aziz

Study. Asian Journal of University Education, 17(3), 119-129.

Nagaletchimee, A. (2019). How Malaysian Lecturers View MOOC And Its Challenges. Journal of Nusantara Studies (JONUS), 4(2), 144-167.

Nassr, R. M., Aborujilah, A., Aldossary, D. A., and Aldossary, A. A. A. (2020). Understanding education difficulty during covid-19 lockdown: Reports on Malaysian university students' experience. IEEE Access, 8, 186939-186950.

Naz, F., and Murad, H. S. (2017). Innovative teaching has a positive impact on the performance of diverse students. SAGE Open, 7(4), 1-8.

Paul, S. A., Priyadarshini, H. R., Fernandes, B., Abd Muttalib, K., Western, J. S., and Dicksit, D. D. (2019). Blended classroom versus traditional didactic lecture in teaching oral surgery to undergraduate students of dentistry program: A comparative study. Journal of International Oral Health, 11(1), 36

Rahim, R. E. A., Der, C. S., and Din, N. M. (2020). Development of an Interdisciplinary Blended Learning Module for Postgraduate Research Methodology Course. ACM International Conference Proceeding Series, 15-19.

Ramli, M. F., Majid, M., and Badyalina, B. (2020). Impeding Factors Towards the Effectiveness of Online Learning During Covid-19 Pandemic among Social Sciences Students. International Journal of Learning and Development, 10(4), 37.

Roslan, N. S., and Halim, A. S. (2021). Enablers and barriers to online learning among medical students during COVID-19 pandemic: An explanatory mixed-method study. Sustainability (Switzerland), 13(6086), 1-15.

Siti Fatimah, A. R., Md Yunus, M., and Hashim, H. (2019). An overview of flipped learning studies in Malaysia. Arab World English Journal, 10(4), 194-203.

Smidt, E., Chau, M. H., Rinehimer, E., and Leever, P. (2021). Exploring engagement of users of Global Englishes in a community of inquiry. System, 98(102477), 1-16.

Smidt, E., Mei Cheong, C. Y., Dachroeden, E., and Kochem, T. (2019). The meaning of quality in online/blended courses to American and Malaysian administrators, faculty, and students. International Journal of Distance Education Technologies, 17(2), 45-58.

Su Ping, R. L., Verezub, E., Adi Badiozaman, I. F. bt, and Chen, W. S. (2020). Tracing EFL students' flipped classroom journey in a writing class: Lessons from Malaysia. Innovations in Education and Teaching International, 57(3), 305-316.

Techanamurthy, U., Alias, N., and Dewitt, D. (2020). A problem-solving flipped classroom module: Developing problem-solving skills among culinary arts students. Journal of Technical Education and Training, 12(4), 39-47.

Wasriep, M. F., and Lajium, D. (2019). 21st century learning in primary science subject via flipped classroom method: A teachers' perspective. International Journal of Recent Technology and Engineering, 8(2 Special Issue 9), 952-959.

Wong, S. F., Mahmud, M. M., and Wong, S. S. (2020). Effectiveness of Formative E-assessment Procedure: Learning Calculus in Blended Learning Environment. ACM International Conference Proceeding Series, 5, 77-82.

Zainuddin, Z., and Attaran, M. (2016). Malaysian students' perceptions of flipped classroom: A case study. Innovations in Education and Teaching International, 53(6), 660-670

ISSN: 2229-9327 